\author{
Bogusław Wyderka \\ Uniwersytet Opolski \\ Instytut Językoznawstwa \\ ORCID 0000-0002-0822-6034; e-mail: wyderka@uni.opole.pl
}

\title{
Ogólnopolska kariera śląskiego wulgaryzmu
}

\begin{abstract}
Abstrakt: Artykuł omawia dzieje wulgaryzmu ciul, który z dialektu śląskiego przeszedł do odmiany potocznej polszczyzny ogólnej. Po raz pierwszy wulgaryzm zapisano w 1875 r. w śląskich dokumentach sądowych. Leksem pochodzi z gwar czeskich (por. culik 'warkocz, spleciona kępa włosów') lub morawskich (culik 'sopel'). Pierwotne znaczenie uległo metaforyzacji i zaczęło oznaczać 'narząd męski, penis'. Wyraz ciul jako wulgaryzm zaczął być używany w funkcji wyzwiska, co dokumentują zapisy archiwalne. W różnych typach kontaktów owo obraźliwe określenie mężczyzny łatwo zmieniało semantykę i ekspresyjne zabarwienie, od 'oszusta, szumowiny' po 'niedorajdę, głupka'. Pierwotne wulgarne znaczenie leksemu rozszczepiało się na kolejne warianty, które zaczęły się neutralizować i tracić więź semantyczną z pierwotnym znaczeniem wulgarnym. Z kolei szerokie ramy kontaktów kulturowo-językowych w relacjach ponadregionalnych umożliwiły zadomowienie się ekspresywizmu w polszczyźnie potocznej. Proces dokonywał się w miarę dynamicznie, ponieważ w rozprzestrzenianiu się leksemu i nowych znaczeń dużą rolę odgrywały społecznościowe media cyfrowe.
\end{abstract}

Słowa kluczowe: wulgaryzm ciul, zmiany semantyczne, etymologia.

Abstract: Polish nationwide career of Silesian vulgarism. The article discusses the history of the vulgarism ciul transferred from the Silesian dialect to colloquial Polish. It was mentioned for the first time in 1875 in Silesian court documents. The lexeme derives from Czech dialects (compare culik 'plait, plaited clump of hair') or Moravian dialects (culik 'icicle'). The primary meaning has been metaphorised to mean 'the masculine organ, the penis'. The word ciul as a vulgarism started to be used as an epithet as documented in archival materials. In various types of interactions, this offensive definition of a male easily changed its semantics and expressive tone from 'trickster, scum' to 'blunderer, fool'. The primary vulgar meaning of the lexeme morphed into subsequent variations that would become neutral and lose its sematic relation with its basic vulgar meaning. Intense cultural and linguistic contacts in crossregional contexts enabled the expression to settle down in Polish colloquial language. The process was quite dynamic with social media playing an important role in spreading the lexeme and its new meanings.

Keywords: vulgarism $\mathrm{ciul}$, semantic development, etymology.

Trudno dziś w tonacji wyłącznie pozytywnej charakteryzować język współczesnego dyskursu politycznego w Polsce, skoro niemal każdego dnia informowani jesteśmy o przekroczeniach norm dobrego obyczaju językowego w wypowiedziach polityków. Nie chodzi tylko o zjawiska nazwane przez Kazimierza Ożoga pauperyzacją języka polityki, do których badacz zalicza m.in. modę na potoczność, szablonowość, karnawalizację itd. 
[Ożóg 2006, 81-90], lecz przede wszystkim o wulgaryzację wypowiedzi. Szeroko komentowanymi przypadkami użycia wulgaryzmów wywołany został temat niniejszego artykułu, dotyczy znaczenia, sensu i etymologii leksemu ciul.

Przypominam wydarzenia. Przy konstytuowaniu się nowych władz samorządowych województwa śląskiego w 2018 r. doszło do spektakularnej decyzji radnego Wojciecha Kałuży o przejściu z Platformy Obywatelskiej do Prawa i Sprawiedliwości, dzięki czemu PiS uzyskało większość w sejmiku województwa śląskiego, zaś radny W. Kałuża objął urząd wicemarszałka województwa. Posłanka Nowoczesnej Monika Rosa na wiecu protestacyjnym w Żorach woła: „Kałuża, ty ciulu!”. Kilka miesięcy później pochodną tego zdarzenia była inwektywa skierowana przez radnego z Piekar Śląskich pod adresem posła PiS, Jerzego Polaczka: „Jurek, jesteś większym ciulem niż Kałuża"’.

W obu przypadkach w funkcji wyzwiska użyte zostało przekleństwo ciul. Jego wydźwięk pragmatyczny natychmiast wywołał dyskusje, nie tylko internetowe, w których ujawniły się różne sądy dotyczące sensu i ekspresywności wyrazu, oceny wahały się na skali od wulgarnego przekleństwa po żartobliwy kolokwializm. Świadczą one o zwiększającym się społecznie przyzwoleniu na używanie wulgaryzmów i rozmywaniu ich negatywnej ekspresywności (dewulgaryzacja) ${ }^{3}$, jak też o zmianach, jakim uległa pierwotna semantyka wyrazu. Dalsze rozważania na temat leksemu ciul wymagają kilku uściśleń teoretycznych odnośnie do terminów: przekleństwo, wulgaryzm, wyzwisko i ich wzajemnych relacji.

Według Macieja Grochowskiego, autora Słownika polskich przekleństw $i$ wulgaryzmów, przekleństwem jest ,jednostka leksykalna, za pomocą której mówiący może W sposób spontaniczny ujawniać swoje emocje względem czegoś lub kogoś, nie przekazując żadnej informacji” (Grochowski 2008, 17). Nie każde przekleństwo jest wulgaryzmem. Za wulgaryzmy uznamy te jednostki leksykalne, które ujawniają emocje nadawcy względem kogoś lub czegoś, przy czym nadawca łamie tabu językowe. Istotną cechą semantyczną wyrażenia wulgarnego jest fakt, że co najmniej jedno z jego znaczeń ma związek z intymną częścią ciała lub czynnością fizjologiczną, zazwyczaj z aktem seksualnym (Grochowski 2008, 19). Wyprzedając nieco tok wywodu, można podkreślić, że warunek ten spełnia charakteryzowany tu wyraz ciul. Z kolei wyzwisko zdefiniowane zostało jako „spontanicznie wypowiedziane wyrażenie, ujawniające emocje mówiącego względem adresata; może ono być użyte po to, aby adresat wiedział, że mówiący czuje względem niego coś złego, i żeby adresat czuł sie źle z tego powodu. Wyzwiska nie są odrębnymi jednostkami systemu leksykalnego, lecz wytworami aktów mowy" (Grochowski 2008, 21). Wyzwiskami bywają nie tylko wulgaryzmy i przekleństwa. Wulgaryzmy nie tworzą zamkniętego zbioru jednostek, stąd zbiory wyrazów uważanych za wulgarne w różnych środowiskach społecznych, w różnych pokoleniach użytkowników języka, nie pokrywają się (Grochowski 2008, 21). Ten sam wulgaryzm

${ }_{1}$ Przebieg zdarzenia podaję za portalem Wyborcza.pl z 24.11.2018 r., https://katowice.wyborcza.pl (dostęp 15.09.2019).

2 Podaję za: katowice.wyborcza.pl z dn. 15.04.2019 (dostęp 15.09.2019).

${ }^{3}$ Na procesy te zwracało uwagę wielu badaczy, m.in. Kowalikowa 1994; 2000; Grybosiowa 1998; Zarzeczny, Mazurek 2009. 
bywa odmiennie wartościowany w różnych kręgach społecznych w zależności od obowiązującyh w tych środowiskach norm obyczajowych. Fakt ten odzwierciedliły również wspomniane dyskusje związane z publicznym użyciem wyzwiska ciul.

Współczesny ogólnopolski leksem CIUL ma pochodzenie gwarowe śląskie. Przemawia za tym kilka faktów: dokumentacja historyczna, liczba i koncentracja geograficzna notowań wyrazu i jego derywatów w materiałach dialektologicznych ${ }^{4}$.

Pierwsze potwierdzenie funkcjonowania na Śląsku wulgaryzmu ciul odnajdujemy w XIX wieku w archiwalnych protokołach rozjemców sądowych okręgu sądowego Strzelce Opolskie ${ }^{5}$. W sporządzonym na podstawie tych materiałów przez Małgorzatę Iżykowską Słowniku śląskich wyzwisk, obelg $i$ wypowiedzeń obraźliwych (Iżykowska, Starczewska-Wojnar 2015) odnajdujemy hasło ciul w znaczeniu 'penis', wyraz pojawia się w protokole procesu rozjemczego w Staniszczach Małych z 1875 r.: „Ty złodzieju gminski, boś siągi pokradł. Ty cyganie, ty garboczu, dzieci masz żebrakami. Ty nie poradzisz nic robić, jeno Jósefie ciula do zici [rzyci] wrazić" (Iżykowska, Starczewska -Wojnar 2015, 92). Dalsza dokumentacja zawarta w haśle pokazuje użycie wulgaryzmu ciul w funkcji wyzwiska w latach trzydziestych XX w., por. „Du pieronischer Ziull [ciul], du Affe, du Pieron” (Jemielnica 1935 r.); „Te Beku [byku]; Te Zulu [ciulu], du Lui, te pieronski Zulu, te Wole" (Rozmierz 1932 r.) (Iżykowska, Starczewska-Wojnar 2015, 92).

W tymże Słowniku śląskich wyzwisk... odnotowano również derywaty ciulek i ciuloń. Ciulek 'zdr. ciul, penis' pojawił się w protokole z Kielczy z 1876 r.: „Kurwjorzu, twoja Zuna [tj. żona] cziebie [tobie] przed Wesselem Zulka [ciulka] z galot w Kaczmie dobua [dobyła]" (Iżykowska, Starczewska-Wojnar 2015, 92). Formę ciuloń "wyzwisko ciul' dokumentują zapisy: „Ty byku, ty kindrozie, jajoniu, ciuloniu, Twoi ojcowie Ci dali kocia na wiano, Tyś z Krascheowa [tj. z Krasiejowa] do małych Staniszcz zgołą rzycią przyszedł, Ty kurwiożu” (Staniszcze Małe 1884); „Piontek, du Culon” (Staniszcze Wielkie 1931) (Iżykowska, Starczewska-Wojnar 2015, 93).

Pierwsze leksykograficzne notowanie form z rdzeniem ciul-odnajdujemy w monografii Lucjana Malinowskiego O niektórych wyrazach ludowych polskich (1892). Badacz przytacza pochodzące z gwar Śląska Cieszyńskiego formy culka, ciulka w znaczeniu 'penis' i odnosi ich pochodzenie do czeskiego culik 'nodus capillorum' (Malinowski 1892, 29), tj. 'warkocz, węzeł, pęk włosów'. Za Malinowskim wyraz odnotowuje M. Karłowicz w Stowniku gwar polskich: culka albo ciulka 'penis' ciesz. (KarSGP, I, 261).

Materiał historyczny wskazuje, że już w 2. poł. XIX w. rozpowszechnienie wulgaryzmu ciul na Śląsku (przynajmniej środkowym i południowym) szło w parze z pojawianiem się jego ekspresywnych derywatów. Trudno powiedzieć, czy w przyszłości odnajdziemy poświadczenia chronologicznie wcześniejsze.

$\mathrm{W}$ 2. poł. XX w. wyraz ciul 'penis' pojawia się niemal we wszystkich gwarach środkowego i południowego Śląska, por. przykładowo: Ale mo tego ciula (SłCiesz);

${ }^{4}$ Wnioski opieram na dostępnych opracowaniach dialektologicznych, przede wszystkim na ZarębaAJŚ, m. 634, SGŚ, SGP PAN.

5 Rozjemcy sądowi stanowili najniższą instancję sądową w państwie pruskim. O instytucji rozjemców zob. Iżykowska, Starczewska-Wojnar 2015, 9-34. 
Dej pozór, bo ci ciul kabzóm wylejzie (SGŚ) ${ }^{6}$. Z reguły występuje obocznie z synonimem ciulok, ciulik, rzadziej ciulka. Wyjątek stanowią gwary północnośląskie okolic Kluczborka i Namysłowa, gdzie w znaczeniu 'penis' notowano tylko formę ciulik, (zob. ZarAJŚ, m. 634). Wyraz utrwalił się także we frazeologii, por. zrobić kogoś w ciula 'oszukać, okłamać'; ciula wziąć ‘nie osiągnąć żadnych korzyści’ (SGŚ).

O śląskim rodowodzie leksemu CIUL świadczy również geografia derywatów z rdzeniem ciul- tworzących bogate gniazdo słowotwórcze. Wyłącznie w gwarach śląskich w znaczeniu 'penis', w różnych jego odcieniach, pojawiają się: ciulaczek, ciulak, ciulczart, ciuliczek, ciulka. Granice gwar śląskich przekroczył jedynie ciulik notowany też w innych gwarach polskich, zob. (SGŚ, SGP PAN).

Ciul używany był często w funkcji obraźliwego wyzwiska, co dokumentują już najdawniejsze zapisy wyrazu i późniejsze liczne notowania z wielu gwar śląskich. Od wyzwiska mającego charakter zniewagi i niosącego znamiona obelżywości łatwo już do modyfikacji semantyki i pojawienia się nowego znaczenia 'niedorajda, fujara, głupiec' lub podobnego, wyrażającego dezaprobatę nazywanej osoby. Taka modyfikacja dokonała się już na gruncie gwar śląskich, por. $Z$ takim ciulem nie chcym mieć nic spólnego (SłCiesz, 73); ti ćulu! Góra św. Anny strzel (OleschAn, 23); ty ciulu, wynoś się Kalety (Jędrysek) tar (SGP PAN, IV, 432); Kobiór pszcz; Żory; ty ciulu jedyn, tak się dosz wykiwać Zabrze; Kochanowice lub; ty ciulu gupi, motor ześ mi zepsuł Łagiewniki M lub; Nędza rac; ty ciulu, zobejż, co żejś zrobit Kolonowskie strzel; Chrząstowice op; Sowin nys (SGŚ, V, 129). Stąd już łatwo do modyfikacji znaczenia.

Poza Śląskiem ciul w znaczeniu 'penis' występuje w przyległych do Śląska rejonach Małopolski zachodniej, co niewątpliwie jest skutkiem wpływów śląskich. Wulgaryzm notowano w Żabnicy pow. żywiecki, Głębowicach pow. oświęcimski, Starczy pow. częstochowski (ZarAJŚ, m. 634), w gwarach górali żywieckich (Nowak 2012, 68). Wyjątkowo pojawia się ciul 'penis' w gwarach rejonów odległych od Śląska: w Przewrotnem pow. rzeszowski (zapis z r. 1969/1970), w Samocicach pow. Dąbrowa Tarnowska (zapis z lat 50. XX w.), w Kórniku pow. poznański (zapis z r. 1930/1932) (SGP PAN). Na podstawie tak nielicznych i rozsianych geograficznie notowań (do tego zapisów różnych chronologicznie), trudno doszukiwać się jakichkolwiek regularności. Odnosi się to również do wtórnego znaczenia 'obelżywie o mężczyźnie', które poza Śląskiem pojawia się gwarze podhalańskiej (KąśPodhale, II, 199) i orawskiej (KąśOrawa, 86), w gwarze Samocic pow. dąbrowski. Zaś w znaczeniu 'mężczyzna niezaradny, ślamazarny; niezdara, niedołęga' notowany był w gwarach miejscowości: Przedmość gm. Praszka (Wieluńskie), Przysiersk pow. świecki (Kociewie), Nienadówka pow. rzeszowski (SGP PAN).

Pochodzenie leksemu CIUL nie jest łatwe do ustalenia. Nie odnajdziemy etymologii wyrazu $\mathrm{w}$ istniejących słownikach etymologicznych polszczyzny. Nie podzielam

\footnotetext{
${ }^{6}$ Mimo że wulgaryzm ciul nie należy do wyrazów rzadko używanych, nie wszystkie popularne słowniczki gwar śląskich go odnotowują. Działa autocenzura powodowana negatywnym nacechowaniem wyrazu. Na temat wulgarnego znaczenia słowa dziennikarz „Dziennika Zachodniego”, Marcin Zasada, przeprowadził wywiad z Rafałem Adamusem, prezesem towarzystwa Pro Loquela Silesiana, który stwierdził: „Wśród śląskich przekleństw, «ciul» ma najcięższy kaliber. Są regiony kraju, w których wydźwięk tego słowa jest łagodniejszy. Ale ja bym się obraził, gdyby ktoś mnie tak nazwał. Warszawiak może mniej” (https://dziennikzachodni.pl/ciul-to-wulgaryzm-jeden-z-najciezszych-na-slasku/ar/550745).
} 
wywodów etymologicznych zaproponowanych Ludwika Stommę oraz Zbigniewa Kadłubka. Słownik polskich wyzwisk, inwektyw i określeń pejoratywnych L. Stommy zawiera hasło: „CIUL, CIULOSEK - od ciułać. W pierwotnym znaczeniu - centuś, skąpiec. Potem również złodziej (...) a także oferma, safanduła" (Stomma 2000, 32)7. Zaś Z. Kadłubek wyprowadza ciula od stpol. ciuły w znaczeniu 'głupiec's. Obaj autorzy wychodzą od zmodifikowanego już znaczenia leksemu ciul, nie biorąc pod uwagę pierwotnego znaczenia 'penis', w jakim wyraz pojawił się w dokumencie z 1875 r.

Wychodząc od sugestii L. Malinowskiego (1892), źródła wyrazu można dopatrywać się w języku czeskim, w którym hipotetyczny rdzeń *cul odnajdujemy w dawnym i gwarowym czeskim culík 'warkocz, spleciona kępa włosów' (Machek 1997, 90). Inny etymolog czeski, Jiři Rejzek, widzi związek interesującego nas wyrazu z czasownikiem culiti 'zaplatać' (Rejzek 2001, 109). Czeskie culik ma powiązanie z gwarowym morawskim culík 'sopel' (Bartoš 1906, 453), a także z dialektalnym słowackim culik 'mięsisty wyrostek na skórze' (Ripka 1994, I, 223). Semantyczne powiązanie znaczenia polskiego ciul, ciulik 'penis' ze znaczeniami występującymi w językach czeskim i słowackim jest wyraźne, pierwotne znaczenie 'warkocz, spleciona kępa włosów' lub 'sopel' zmieniło się, na zasadzie metafory, w znaczenie 'narząd męski, penis'. Analogiczny proces rozwarstwienia znaczeń na zasadzie metafory odnajdujemy w innym polskim wulgaryźmie - kutas (zob. Bańkowski 2000).

W gwarze podhalańskiej występuje hasło CIUL II w znaczeniu 'pompon zrobiony z włóczki lub wełny przyszyty na czubku czapki’ (KąśPodhale, II, 199). Jest to ślad wiążący podhalańską formę ciul z czeskim culik 'warkocz, spleciona kępa włosów'. Gwary śląska i podhalańska mogły dokonać zapożyczeń niezależnie od siebie. Nie mamy jednakże potwierdzeń, aby na Podhalu doszło do wytworzenia się znaczenia 'penis', co jest istotne, mając na uwadze dalszą ewolucję semantyczną wyrazu do obraźliwego wyzwiska oraz rozprzestrzenianie się wulgaryzmu w polszczyźnie ogólnej. Leksemy CIUL I, CIULAS, CIULIK 'obraźliwie o mężczyźnie’, które notuje słownik gwar podhalańskich (KąśPodhale, II, 199), mogą być nowszymi zapożyczeniami z polszczyzny potocznej, niezależnymi od CIUL II.

Ze względów semantycznych mniejsze prawdopodobieństwo należy przypisać hipotezie wiążącej pochodzenie wyrazu z dialektalnym rumuńskim ciul 'zwierzę z obciętymi uszami' (Machek 1997, 108), od którego pochodzi słowackie čuĺa 'owca z krótkimi uszami; koza bez rogów' (Ripka 1994, 283), gw. orawskie ciuła 'owca bez rogów z małymi uszami' (KąśOrawa) oraz gw. podhalańskie cułka 'owca o krótkich uszach' (KąśPodhale, II).

Zamieszczony w prezentowanym artykule profil diachroniczny leksemu CIUL ${ }^{9}$ pokazuje, że wyraz we współczesnej polszczyźnie ogólnej zaczął się pojawiać w początkach lat dziewięćdziesiątych ub. wieku.

7 Według Andrzeja Bańkowskiego czasownik ciułać jest derywatem pochodnym od pol. dial. ciuła (Bańkowski 2000), nie mógł więc fundować rzeczownika ciul. Trudna do wyjaśnienia na gruncie polskiej fonetyki historycznej jest też początkowa grupa ciu-.

8 Zob. https://gryfnie.com/slownik-slaski/ciul/ (dostęp 30.09.2019). Co do etymologii ciuły zob. poprzedni przypis. lodz.p1/.

${ }^{9}$ Cytuję według danych Narodowego Korpusu Języka Polskiego (wyszukiwarka Pelcra), www.nkjp.uni. 

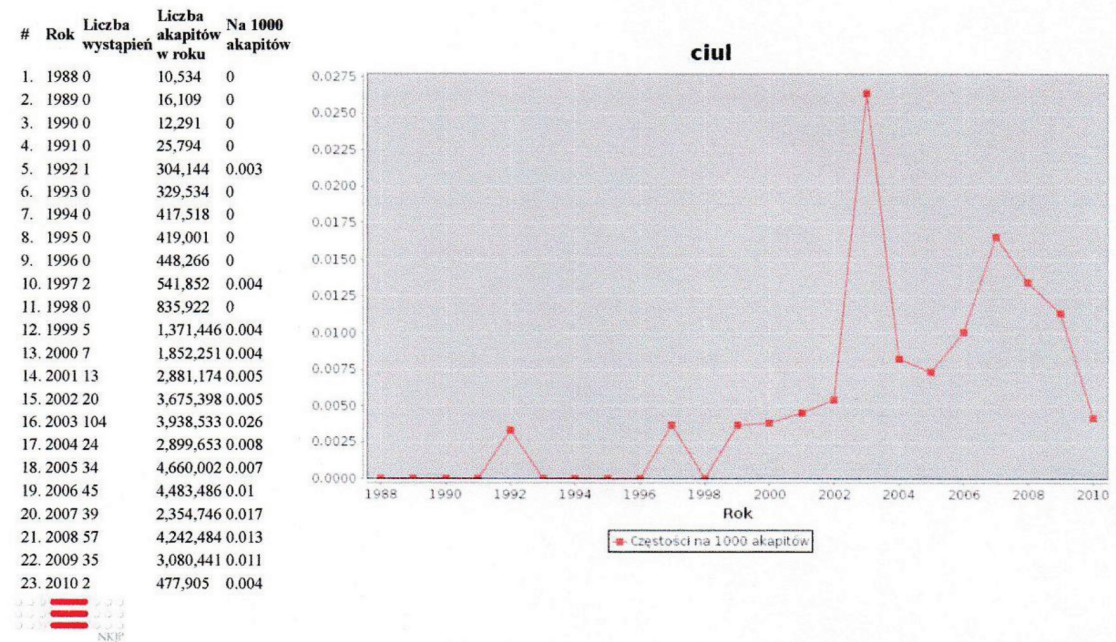

Ryc. 1. Profil diachroniczny leksemu CIUL

Źródło: Narodowy Korpus Języka Polskiego, www.nkjp.uni.lodz.pl.

Nie dziwi zatem fakt, że hasła CIUL nie zawierają XX-wieczne słowniki ogólne języka polskiego czy nowsze, oparte na XX-wiecznych korpusach (SJPDor, SJPDubisz, WSJP, WSJP PWN). Skoro wymienione słowniki zawierają hasło chuj (z wyjątkiem SJPDor), to nie wchodzą w grę względy cenzuralne. Najprawdopodobniej redaktorzy tych słowników uznali wyraz ciul za regionalny bądź slangowy. Natomiast interesujący nas leksem odnajdujemy w PSWP, w którym CIUL opisano w znaczeniu już zmodyfikowanym jako wyraz pogardliwy 'ktoś niezaradny, nierozgarnięty, pozbawiony energii'. Tamże odnotowano również podhasło ciul miejski 'mieszczuch'.

Brak też interesującego nas wyrazu w słownikach polszczyzny historycznej ${ }^{10}$ i słownikach etymologicznych, co wynika z braku potwierdzeń w źródłach. Kiedy wulgaryzm zadomowił się w gwarach śląskich i czy w ogóle uda się to stwierdzić, trudno powiedzieć. Jednakże nie przypuszczam, aby ciul pojawił się w gwarach śląskich dopiero w 2. poł. XIX w., był już wtedy zadomowiony, o czym świadczą przytoczone wyżej fragmenty protokołów sądowych.

Nie odnajdujemy interesującego nas leksemu w Słowniku polskich przekleństw $i$ wulgaryzmów Macieja Grochowskiego (2008). Autor z założenia uwzględnia wyłącznie wyrazy o zasięgu ogólnopolskim, stąd można wysnuć wniosek, że w okresie gromadzenia zbioru przekleństw (pierwsze wydanie Słownika 1995 r.), słowo ciul było uważane za regionalizm lub argotyzm. Fakt ten pokrywa się z danymi cytowanego wyżej profilu diachronicznego wyrazu ciul.

We współczesnej polszczyźnie ogólnej CIUL pojawia się jako leksem odmiany potocznej (lub w stylizacjach na potoczność) w następujących znaczeniach:

1. wulgaryzm 'członek męski, penis; chuj, kutas',

${ }^{10}$ Brak hasła w SłStp, SP XVI, ESJP XVII, LindeSJP, SłWil, SłWar. 
2. pejoratywnie o mężczyźnie 'łotr, bydlak, szumowina, łajdak',

3. lekceważąco o mężczyźnie 'dureń, oferma, ślamazara, łamaga',

4. pełni rolę słowa wytrychu w tekstach potocznych, tj. pojawia się jako forma obsceniczna bez określonego znaczenia, zastępując inny wyraz o zabarwieniu neutralnym lub inny wulgaryzm.

Pełny zakres znaczeń uwzględniają dwa słowniki. Słownik polskich leksemów potocznych pod red. W. Lubasia, w którym hasło ma następującą charakterystykę: 1. 'grubiańsko penis'; 2. 'ślamazara pozbawiony energii', por. A nie będziesz gadat, to dziewczyna gotowa pomyśleć żeś ciul (cyt. z powieści W. Myśliwskiego, Kamień na kamieniu); 3. 'obraźliwie o mężczyźnie' (SPLP, I, 503). Drugim dziełem jest internetowy Miejski słownik slangu $i$ mowy potocznej ${ }^{11}$. W słowniku odnajdujemy następujące znaczenia wyrazu: 1. wulgarnie o osobie, do której czujemy dużą antypatię i mamy całkowity brak szacunku: 'oszust, łotr, szumowina, łajdak', cyt. Ten ciul oszukat mnie na 2 paczki. Znowu muszę spotkać się jutro z tym ciulem. 2. na Śląsku: 'chuj, kutas', cyt. Tyś jes ciul jak al ino nie taki gładki (al = węgorz). 3. 'dureń, oferma', cyt. Ten Karol to jednak jest ciul. Oba słowniki odnotowują też liczne derywaty od podstawy ciul.

Wydany w 1996 r. (a więc w okresie wzrastającej frekwencji użycia wyrazu ciul w polszczyźnie) Słownik polszczyzny potocznej Janusza Anusiewicza i Jacka Skawińskiego dokumentuje dwa znaczenia: 1. obraźliwie 'z niechęcią o mężczyźnie'. 2. grubiańsko 'członek męski’ (Anusiwicz, Skawiński 1996, 19 i 28).

Redagowany przez hobbystów internetowy Słownik języka polskiego (https://sjp.pl) kwalifikuje wyraz jako wulgarny w znaczeniach: 1. 'wyzwisko używane w stosunku do mężczyzn; skurwysyn, chuj'; 2. 'członek męski; fiut'.

Ponadto pierwotne znaczenie wyrazu ciul, tj. 'penis' odnajdujemy w Słowniku seksualizmów polskich Jacka Lewinsona, gdzie poprzedzone jest kwalifikatorem grubiański (Lewinson 1996, 25).

Znaczenia wskazane wyżej jako (2) i (3), tj. 'pejoratywnie o mężczyźnie' i 'lekceważąco o mężczyźnie' nie wykazują ostrej granicy, por. Prawy przedni błotnik klepałem. Jakiś ciul wgniótt na parkingu (www.nkjp.uni.lodz.pl/). Jak już wspominałem, są one efektem wtórnych przesunięć semantycznych, a współcześnie można je uznać za ogólnopolskie kolokwializmy. Używane w komunikacji potocznej bywają różnie odbierane i wartościowane w zależności od typu kontaktu i kontekstu. W kontaktach oficjalnych oba znaczenia traktowane są jako nacechowane pejoratywnie. Ciul użyty w kontaktach nieoficjalnych, koleżeńskich w znaczeniu (3) nie jest odbierany jako ubliżający, bywa natomiast odczytywany jako lekceważenie bądź kpina ${ }^{12}$. Ów nieco łagodniejszy odcień grubiańskości znaczenia, lecz nadal pejoratywny, potwierdzają

11 Zob. https://www.miejski.pl/ (dostęp 17.09.2019). Na stronie brak informacji o składzie redakcji.

${ }^{12}$ Znaczenie to potwierdzają teksty i wpisy internetowe oraz wyniki sondażu, jaki przeprowadziłem w styczniu 2019 r. wśród studentów Uniwersytetu Opolskiego, mając na uwadze potrzeby innego opracowania. W podobnym tonie wypowiada się Zbigniew Kadłubek (Ślązak, profesor filologii klasycznej Uniwersytetu Śląskiego), por. fragment felietonu zamieszczonego na stronie internetowej Gryfnie: „Jak usłyszom ludzie «ty ciulu», zaro sie lachajom choby gupi do syra. Słowo «ciul» ni ma obelżywe. Je w nim coś łagodnego. Teroz sie godo, że to je fest szpetne słowo a downij to było taki normalne" (https://gryfnie.com/ slownik-slaski/ciul/). 
zapisy w nowo opracowanych słownikach, np. Inny słownik języka polskiego PWN pod red. M. Bańki określa omawiany wyraz jako słowo potoczne i obraźliwe: 'ciulem nazywa się mężczyznę, do którego czuje się niechęć' [ISJP I, 199]. Słownik języka polskiego pod red. B. Dunaja, klasyfikuje wyraz jako regionalny, wulgarny: w znaczeniu 'bardzo obraźliwie o mężczyźnie' (SJPDunaj, 129). Jako łódzki regionalizm w znaczeniu 'ktoś niezaradny, oferma, niedorajda' notuje omawiany wyraz Stownik dwudziestowiecznej Łodzi D. Bieńkowskiej, M. Cybulskiego, E. Umińskiej-Tytoń (2007). Hasło CIUL pojawia się w szeregu innych specjalistycznych słowników drukowanych (np. jako argotyzm) i internetowych, zob. m.in. Wikisłownik (https://pl.wiktionary.org/), Glosbe (https://pl.glosbe.com/pl/pl/ciul). Cytowanie ich zawartości nie wnosi nowych danych.

Współcześnie notujemy też formę ciul w funkcji wyrazu wytrychu, por. znaczenie (4), niejednokrotnie o głęboko zneutralizowanej wulgarności. Funkcję (4) ilustruję cytatami zaczerpniętymi z zasobów Narodowego Korpusu Języka Polskiego [www.nkjp.uni.lodz. pl/]: mniej więcej ale mi napisałaś że będziesz godzinę później no to mówię ciul umrę zaraz z głodu; a ciul o Boże a ile ja go widziałam? no i co mówisz Marlena; Gabi):) $u$ mnie $w$ szkole $w$ ciul panienek chodzi $w$ takich trampkach dtugich nie moge tego; za pare dni na kantrole, i ciul wie, co mi lekarz wynajdzie.

Omówione w artykule dzieje leksemu CIUL nie stanowią przypadku szczególnego. Odwrotnie, w świetle faktów opisanych w wydanej ostatnio monografii Benjamina K. Bergena What the F. Co przeklinanie mówi o naszym jezyku, umyśle i nas samych (2019), dzieje śląskiego wulgaryzmu nie odbiegają od przypadków rozwoju wulgaryzmów w społecznościach anglojęzycznych. Zadomowione w gwarach śląskich zapożyczenie, pochodzące z gwar czeskich (o znaczeniu 'warkocz, spleciona kępa włosów') lub morawskich ('sopel') uległo metaforyzacji i zaczęło oznaczać 'narząd męski, penis' (znaczenie notowane na Śląsku w 1875 r.). Ta zmiana semantyki mogła dokonać się jeszcze na gruncie języka macierzystego, lecz tego nie jesteśmy w stanie udokumentować. Ciul jako wulgaryzm zaczął być używany w funkcji wyzwiska, co dokumentują zapisy archiwalne. W różnych typach kontaktów owo obraźliwe określenie mężczyzny łatwo zmieniało semantykę i ekspresyjne zabarwienie, od 'oszust, szumowina' po 'niedorajda, głupek'. Pierwotne wulgarne znaczenie leksemu rozszczepiało się na kolejne warianty, które zaczęły się neutralizować i tracić więź semantyczną z pierwotnym znaczeniem wulgarnym. Z kolei szerokie ramy kontaktów kulturowo-językowych $\mathrm{w}$ relacjach ponadregionalnych umożliwiły zadomowienie się ekspresywizmu w polszczyźnie potocznej. Proces dokonywał się w miarę dynamicznie, ponieważ w rozprzestrzenianiu się leksemu i nowych znaczeń dużą rolę odgrywały społecznościowe media cyfrowe.

\section{Literatura}

Anusiewicz J., Skawiński J. (1966), Stownik polszczyzny potocznej, Warszawa-Wrocław.

Bańkowski A. (2000), Etymologiczny słownik języka polskiego, t. 1-2, Warszawa.

Bartoš F. (oprac.) (1906), Dialektický slonvik moravský, Praha. 
Bergen B.K. (2019), What the F. Co przeklinanie mówi o naszym języku, umyśle i nas samych, Kraków.

Bieńkowska D., Cybulski M., Umińska-Tytoń E. (2007), Słownik dwudziestowiecznej Łodzi, Łódź. ESJPXVII, Elektroniczny słownik języka polskiego XVII i XVIII wieku (https://sxvii.pl/).

Grochowski M. (2008), Stownik polskich przeklenstw i wulgaryzmów, wyd. III, Warszawa.

Grybosiowa A. (1998), Liberalizacja społecznej oceny wulgaryzmów, [w:] Człowiek - dzieło sacrum, pod red. S. Gajdy i H.J. Sobeczki, Opole, s. 361-369.

ISJP, Inny słownik języka polskiego PWN, red. M. Bańko, t. 1-2, Warszawa 2000.

Iżykowska M., Starczewska-Wojnar A. (2015), „Ty bestya! Ty kamelo!”. Agresja językowa w polszczyźnie ślaskiej (1845-1938), Opole.

KarSGP, Karłowicz J., Stownik gwar polskich, t. I-VI, Kraków 1900-1911.

KąśOrawa, Kąś J., Stownik gwary orawskiej, Kraków 2003.

KąśPodhale, Kąś J., Ilustrowany leksykon gwary i kultury podhalańskiej, t. II, Bukowina Tatrzańska-Nowy Sącz 2015.

Kowalikowa J. (1994), Znaczenie i funkcja wyrazów tzw. brzydkich we współczesnej polszczyźnie mówionej, (w:) Wspótczesna polszczyzna mówiona w odmianie opracowanej (oficjalnej), pod red. Z. Kurzowej i W. Śliwińskiego, Kraków, s. 105-113.

Kowalikowa J. (2000), Wulgaryzmy we współczesnej polszczyźnie, [w:] Język trzeciego tysiąclecia, pod red. G. Szpili, Kraków, s. 121-132.

LindeSJP, Linde S.B., Stownik języka polskiego, t. 1-4, Warszawa 1807-1814.

Lewinson J. (1996), Stownik seksualizmów polskich, Warszawa.

Machek V. (1997), Etymologický slovník jazyka českého, Praha.

Malinowski L. (1892), O niektórych wyrazach ludowych polskich. Zapiski porównawcze, Kraków.

Miejski słownik slangu i mowy potocznej (https://www.miejski.pl/).

Narodowy Korpus Języka Polskiego (www.nkjp.uni.lodz.pl/).

Nowak J.K. (2012), Słownik gwary górali żywieckich, Żywiec-Grójec-Warszawa.

OleschAn, Olesch R. (1958-1959), Der Vorschatz der polnischen Mundart von Sankt Annaberg, Bd I-II, Berlin.

Ożóg K. (2006), Pauperyzacja języka wspótczesnej polityki, „LingVaria” nr 1, s. 81-90.

PSWP, Praktyczny słownik współczesnej polszczyzny, red. H. Zgółkowa, t. 1-50, Poznań 19942005.

Rejzek J. (2001), Český etymologický slovnik, Praha.

Ripka I. red., 1994, Slovník slovenských nárečí, t. 1, Bratislava.

SGP PAN, Stownik gwar polskich, opracowany przez Zakład Dialektologii Polskiej Instytutu Języka Polskiego Polskiej Akademii Nauk w Krakowie, t. 1-2, red. M. Karaś, t. 3-5, red. J. Reichan, Wrocław-Kraków 1979-1998; t. 6-7, red. J. Okoniowa, Kraków 2001-2013.

SGŚ, Stownik gwar ślaskich, t. 1-XVI, red. B. Wyderka, Opole 2000-2017.

SJPDor, Stownik języka polskiego, t. 1-11, pod red. W. Doroszewskiego, Warszawa 1958-1969.

SJPDubisz, Uniwersalny stownik języka polskiego, t. 1-4, pod red. S. Dubisza, Warszawa 2003.

SJPDunaj, Stownik współczesnego języka polskiego, red. B. Dunaj, Warszawa 1996.

SłCiesz, Słownik gwarowy Ślaska Cieszyńskiego, pod red. J. Wronicz, wyd. II, Ustroń 2010. 
Stownik języka polskiego (https://sjp.pl/).

SłStp, Stownik staropolski, red. S. Urbańczyk, t. 1-11, Wrocław-Warszawa-Kraków-Gdańsk 1953-2002.

SłWar, Stownik języka polskiego, t. 1-8, pod red. J. Karłowicza, A. Kryńskiego i W. Niedźwiedzkiego, Warszawa 1900-1927.

SłWil, Stownik języka polskiego, A. Zdanowicz i in., t. 1-2, Wilno 1861.

SPXVI, Stownik polszczyzny XVI w., t. III: BY-CYZ, Wrocław-Warszawa-Kraków 1968.

SPLP, Stownik polskich leksemów potocznych, red. W. Lubaś, t. 1: A-Ć, Kraków 2001.

Stomma L., 2000, Stownik polskich wyzwisk, inwektyw i określeń pejoratywnych, Warszawa.

WSJP, Wielki słownik języka polskiego IJP PAN, red. P. Żmigrodzki (www.wsjp.pl/).

WSJP PWN, Wielki stownik języka polskiego PWN, t. 1-5, pod red. S. Dubisza, Warszawa 2018.

ZarAJŚ: Zaręba A., Atlas językowy Śląska, t. I-VIII, Warszawa-Kraków 1969-1990.

Zarzeczny G., Mazurek M. (2009), Co komunikuja polskie wulgaryzmy?, [w:] Procesy rozwojowe współczesnej polszczyzny, cz. 1: Najnowsze zjawiska w polszczyźnie, pod red. K. Zalejarza i K. Ruty, Poznań, s. 174-183. 